\title{
Genotoxicity evaluation of two metallic-insecticides using Allium cepa and Tradescantia pallida: A new alternative against leaf-cutting ants
}

\author{
Raphael Bastão de Souza, Cleiton Pereira de Souza, Odair Correa Bueno, \\ Carmem Silvia Fontanetti*
}

UNESP - Univ Estadual Paulista, Institute of Biosciences, Department of Biology, Rio Claro, São Paulo, Brazil

\section{H I G H L I G H T S}

- The genotoxic potential of two new metallic-insecticides was evaluated.

- Only one of them induced genotoxic alterations in Allium cepa.

- The genotoxicity can be related to one of the components of its formula.

- None of them was genotoxic to Tradescantia pallida.

- One of the metallic-insecticide tested is environmentally safer.

\section{A R T I C L E I N F O}

\section{Article history:}

Received 25 August 2016

Received in revised form

23 October 2016

Accepted 24 October 2016

Available online 2 November 2016

Handling Editor: David Volz

\section{Keywords:}

Micronucleus

Chromosomal instability

Ants

Natural formicide

\begin{abstract}
A B S T R A C T
In order to combat leaf-cutting ants, the pesticide sulfluramid used to be the most widely utilized active ingredient. However, its use was banned in 2009 by the Stockholm Convention, although some countries were allowed to continue using it. As an effective alternative to its replacement, researchers developed a metallic-insecticide system, which is a natural product linked to metal complexes. Thus, the aim of this study was to evaluate the ability of these new metallic-insecticides in change the genetic material of non-target organisms. The tests were performed utilizing chromosomal aberrations and micronucleus tests in the Allium cepa test system and the Trad-MCN test in Tradescantia pallida. To better understand the results, one of the components of the formula, 5-methyl-phenanthroline, was also analyzed according to the same parameters. To A. cepa, the results showed that one of the metallic insecticides induced cytotoxicity and genotoxicity at different concentrations, while the other metallic-insecticide showed chromosomal instability only at the highest concentration. The analysis of 5-methyl-phenanthroline revealed that it can be related with the positive results, since genotoxic effects were induced. In the Trad-MCN test, none of the metallic-insecticides showed genotoxic activity, although one of them induced more micronucleus formation.
\end{abstract}

๑) 2016 Elsevier Ltd. All rights reserved.

\section{Introduction}

Leaf-cutting ants of the genus Atta are one of the major pests responsible for economic damage in agricultural areas of tropical and subtropical regions of the Americas (Schoereder et al., 2012). The processes of tackling these organisms have been conducted, historically, through synthetic pesticides (Schoereder et al., 2012), but these methods have low specificity, are highly toxic to nontarget organisms and can cause insect populations to become

\footnotetext{
* Corresponding author.

E-mail address: fontanet@rc.unesp.br (C.S. Fontanetti).
}

resistant (Hebling et al., 1996).

Since the pesticide dodecachlor was banned in 1993, sulfluramid became the most widely used active ingredient against such organisms (Zanuncio et al., 2000; ABRAISCA, 2011). However, both the production and degradation of sulfluramid involves perfluorooctanesulfonate (PFOS), a substance which is toxic to mammals (Luebker et al., 2005; Fan et al., 2005), birds (Verreault et al., 2005; Olivero-Verbel et al., 2006), fish (Taniyasu et al., 2003) and other insects (Bots et al., 2010).

Because of its risk to humans and the environment, in 2009, the Stockholm Convention decided to ban the production of sulfluramid, although countries were allowed to send proposals to 
keep its production when the use was justified (Stockholm Convention, 2009). In the US, all products containing sulfluramid have been banned, and stored products could be marketed until December 2012 (USEPA, 2008).

As an effective alternative to the use of sulfluramid, researchers developed a metallic-insecticide complex. Its formulation contains a natural product, the flavonoid hesperetin, linked to metallic inorganic complexes. Of all the formulations developed, the most effective against leaf-cutting ants were $[\mathrm{Mg}(5-\mathrm{Cl}$-phen)(hesperetin $\left.)\left(\mathrm{H}_{2} \mathrm{O}\right)_{2}\right]\left(\mathrm{CH}_{3} \mathrm{COO}\right)$ and $[\mathrm{Mg}(5$-methyl-phen)(hesperetin) $\left.\left(\mathrm{H}_{2} \mathrm{O}\right)_{2}\right]\left(\mathrm{CH}_{3} \mathrm{COO}\right)$ (Oliveira et al., 2013).

Theoretically, a good formicide cannot upset the balance of the environment and, at the same time, it should be effective only against the target organism. The development of agrochemicals with less toxicity has become of upmost importance, once the concern about the environmental health has increased and several countries have tougher legislation about its application in the environment (Kähkönen and Nordström, 2008). Although the metallic-insecticides are derived from a natural product, its genotoxicity should be evaluated, once flavonoids can change cytochrome P450 activity, cause enzymatic oxidation and inhibit topoisomere II (Macgregor and Jurd, 1978; Middleton and Kandaswami, 1994; Silva et al., 1997; Boersma et al., 2000; Snyder and Gillies, 2003).

For the evaluation of these parameters, well-established experiments performed with higher plants, as Allium cepa and Tradescantia pallida, can be used (Leme and Marin-Morales, 2009; Misik et al., 2011). These bioassays are validated and their protocols are standardized through a program under International Program on Plant Bioassays (IPPB) conducted by the United Nations Environment Program (UNEP) (Ma, 1999). In both tests is possible to evaluate induction of micronuclei to verify genotoxic and chromosomal instability events and, using $A$. cepa, is also possible to evaluate chromosomal aberrations and mitotic index for detection of genotoxicity and cytotoxicity, respectively (Kirsche-Volders et al., 2011; Pedro-Escher et al., 2014). Recently, these organisms have been commonly used worldwide to detect alterations in the genetic material caused by agrochemicals (Rodríguez et al., 2015; Liman et al., 2015; Bianchi et al., 2016; Kuchy et al., 2016), dyes (Ventura-Camargo et al., 2016), sewage sludge (Martins et al., 2016), river water samples (Batista et al., 2016) and drugs (Pichler et al., 2014; Lutterbeck et al., 2015).

Therefore, this study aims to evaluate the toxic, cytotoxic and genotoxic potentials of two metallic-insecticides at three different concentrations using the A. cepa test system and Trad-MCN test. Additionally, for better understanding the results, one of the components of the formula, 5-methyl-phen (5-methyl-phenanthroline), was also evaluated.

\section{Material and methods}

\subsection{Metallic-insecticides}

The metallic-insecticides used in the study, $[\mathrm{Mg}(5-\mathrm{Cl}-\mathrm{phen})(-$ hesperetin) $\left.\left(\mathrm{H}_{2} \mathrm{O}\right)_{2}\right]\left(\mathrm{CH}_{3} \mathrm{COO}\right)$ [1] and [ $\mathrm{Mg}$ (5-methyl-phen)(hesperetin) $\left.\left(\mathrm{H}_{2} \mathrm{O}\right)_{2}\right]\left(\mathrm{CH}_{3} \mathrm{COO}\right)$ [2], as well as one of the components of the formula, 5-methyl-phen [3], were supplied by the Laboratório de Produtos Naturais [Natural Products Laboratory], from the Federal University of São Carlos, Brazil. The concentrations utilized in this study were defined by the developers of the metallic-insecticides based in mortality tests with ants and bees.

\subsection{Soil samples}

The soil used in the A. cepa test system, classified as Oxisol, was collected from the campus of the São Paulo State University, municipality of Rio Claro, São Paulo, Brazil (22 $\left.24^{\prime} 36^{\prime \prime} \mathrm{S} / 47^{\circ} 33^{\prime} 36^{\prime \prime} \mathrm{W}\right)$. The samples were sieved (mesh $<\mathrm{mm}$ ), homogenized and dried at room temperature.

\subsection{Germination of $A$. cepa seeds}

Approximately 100 seeds of $A$. cepa from the same lot and variety (Baia periform) were placed in Petri dishes with approximately $35 \mathrm{~g}$ of soil in order to evaluate the toxic, cytotoxic and genotoxic potentials of the substances under test. The positive control group was conducted with seeds exposed to two compounds at potentially toxic concentrations: the herbicide trifluralin, aneugenic agent, at the concentration of $0.019 \mathrm{ppm}$ (Fernandes et al., 2007) and methyl methanesulfonate (MMS), clastogenic agent, at the concentration of $4 \times 10^{-4} \mathrm{M}$ (Rank and Nielsen, 1997). The negative control (NC) was performed in Petri dish containing only control soil. The exposures to the substances under test were carried out at the following concentrations: $0.5 \mathrm{mg} / \mathrm{L}, 1.0 \mathrm{mg} / \mathrm{L}$, and $2.0 \mathrm{mg} / \mathrm{L}$. The tests were performed in duplicate.

\subsection{Preparation of the slides of A. cepa}

After five days of exposure to the substances and to the positive and negative controls, the radicles, approximately $2 \mathrm{~cm}$ in length, were collected and fixed in Carnoy 3:1 (ethanol:acetic acid, v/v) for 6-12 h. After this process, the radicles were transferred to a new Carnoy fixative and stored at $4{ }^{\circ} \mathrm{C}$ until use. For the preparation of the slides, the radicles were hydrolyzed in $1 \mathrm{M} \mathrm{HCl}$ at $60{ }^{\circ} \mathrm{C}$ for $10 \mathrm{~min}$ and, then, submitted to Schiff's reagent for $2 \mathrm{~h}$ (Mello and Vidal, 1978). Both the meristematic and the $F_{1}$ region were sectioned and placed on the slide. To enhance the coloration and improve cell spreading, one drop of $2 \%$ acetic carmine was added, and, shortly thereafter, the material was covered with a coverslip. The coverslips were removed in liquid nitrogen and the permanent slides were mounted with Entellan ${ }^{\circledR}$. The slides were examined under a light microscope at $1000 \times$ magnification.

\subsection{Evaluation of the toxic, cytotoxic and genotoxic potential in meristematic cells of A. cepa}

In total, approximately 10,000 cells were analyzed for each treatment and for the positive and negative controls. Toxicity was calculated through the seeds' germination index (GI). Cytotoxicity was assessed based on the mitotic index [(MI $=\mathrm{n}^{\circ}$ of dividing cells/ total $n^{\circ}$ of cells observed)x100]. The genotoxicity was analyzed based on the number of cells carrying chromosomal aberrations (CA), such as nuclear buds, anaphasic and telophasic bridges and Cmetaphases. The Genotoxicity Index (GenI) was calculated through the formula GenI $=\left(n^{\circ}\right.$ of cells with chromosomal aberrations $/ n^{\circ}$ of cells observed)x100. The Frequency of Micronuclei (FMN) was determined through the number of cells carrying micronuclei (MN) through the formula $\mathrm{FMN}=\left(\mathrm{n}^{\circ}\right.$ of cells with $\mathrm{MN} / \mathrm{n}^{\circ}$ of cells observed)x100. The analysis of the presence of micronuclei can be used as a biomarker of genotoxic and chromosomal instability events, which, if not repaired, indicate mutagenic effect.

The results were compared with the negative control through the Kruskal-Wallis test $(\mathrm{p}<0.05)$.

\subsection{Evaluation of cells with micronuclei in the $F_{1}$ region of $A$. cepa}

The $F_{1}$ region was analyzed in order to determine the damage suffered by the meristematic cells when the FMN of the meristematic region was significant and, thus, confirm the indication of mutagenicity. For this purpose, 10,000 cells of the $F_{1}$ region of each 
treatment were analyzed and the number of cells with MN was counted in order to determine the FMN.

The statistical analysis was conducted by comparing the treatments with the negative control using the Kruskal-Wallis test $(\mathrm{p}<0.05)$.

\subsection{Preparation of the slides and evaluation of the genotoxicity potential in T. pallida}

The Trad-MN test was developed based in Ma et al. (1994). Inflorescences of T. pallida were collected in the Experimental Garden of the São Paulo State University, Rio Claro, Brazil. To evaluate genotoxicity, ten young inflorescences were placed in bakers for $8 \mathrm{~h}$ under constant aeration with three different concentrations of the metallic-insecticides diluted in water $(0.5 \mathrm{mg} / \mathrm{mL} ; 1.0 \mathrm{mg} / \mathrm{mL}$ and $2.0 \mathrm{mg} / \mathrm{mL}$ ). After this period of exposure, the inflorescences were transferred to bakers containing ultrapure water for $24 \mathrm{~h}$ in order to allow recovery. The same protocol was followed to the negative control (ultrapure water) and positive control $\left(7.7 \times 10^{-3} \mu \mathrm{L} / \mathrm{mL}\right.$ of methyl metanesulphonate). Then, the material was fixed in Carnoy's solution for $48 \mathrm{~h}$ and the medium-sized buds were chosen to prepare the slides. The buds were placed on a slide and macerated with a razor blade to release the tetrads. A drop of $2 \%$ acetic carmine was added to the material in order to facilitate the procedure and demonstrate the presence of micronucleated tetrads. The material was coverslipped and the slides were quickly passed over a flame. Ten slides were analyzed per treatment under a light microscope and a total of 3,000 tetrads were examined per treatment. In order to evaluate genotoxicity, the frequency of micronucleus was calculated through the formula $\mathrm{FMN}=\left(\mathrm{n}^{\circ}\right.$ of tetrads with micronucleus $/ \mathrm{n}^{\circ}$ of cells observed) $\times 100$. The test was performed in duplicate and the results obtained after exposure to the metallicinsecticides were compared to the negative control using the Kruskal-Wallis test $(\mathrm{p}<0.05)$

\section{Results}

\subsection{Allium cepa test system}

3.1.1. Metallic-insecticide $[\mathrm{Mg}(5-\mathrm{Cl}-$ phen)(hesperetin $\left.)\left(\mathrm{H}_{2} \mathrm{O}\right)_{2}\right]\left(\mathrm{CH}_{3} \mathrm{COO}\right)$ [1]

The compound did not affect the germination rate of the seeds and the mitotic index of the cells (Table 1). Genotoxic effects were significant only at the highest concentration tested, $2.0 \mathrm{mg} / \mathrm{L}$ (Table 1). The main aberrations observed were nuclear buds and anaphasic bridges (Fig. 1A and B). In the meristematic cells of the highest concentration, $2.0 \mathrm{mg} / \mathrm{L}$, the presence of micronuclei (Fig. 1C) suggests chromosomal instability. In order to evaluate if the micronuclei were transferred and fixed to other regions of the organism and confirm the indication of mutagenicity, cells from the $\mathrm{F}_{1}$ region were analyzed. The data demonstrated that no concentration of the compound had significant result in this region (Table 1).

\subsubsection{Metallic-insecticide $[\mathrm{Mg}(5-$ methyl- phen)(hesperetin) $\left.\left(\mathrm{H}_{2} \mathrm{O}\right)_{2}\right]\left(\mathrm{CH}_{3} \mathrm{COO}\right)$ [2]}

The index of germination revealed no toxicity for this metallicinsecticide (Table 2). Statistically significant cytotoxicity was found at a concentration of $2.0 \mathrm{mg} / \mathrm{L}$, once a reduction in the mitotic index was observed. In the meristematic cells, statistically significant genotoxicity was evidenced by the presence of metaphases with adherence (Fig. 1D), nuclear buds and anaphasic bridges at concentrations of $0.5 \mathrm{mg} / \mathrm{L}$ and $1.0 \mathrm{mg} / \mathrm{L}$ (Table 2). However, the statistical analysis revealed no significant number of micronuclei for any concentrations tested (Table 2).

\subsubsection{Analysis of one of the components of the formula, 5-methyl- phenanthroline [3]}

The metallic-insecticide [2] induced statistically significant cytotoxic and genotoxic effects. Therefore, to better understand the results, one of the components of its formulation, 5-methyl-phenanthroline, was also evaluated in order to determine its potential toxicity and, thus, determine whether its presence may be related to the toxicity found. In the meristematic cells, the analysis showed that 5-methyl-phen was able to induce nuclear buds and metaphase with adherence at the concentration of $0.5 \mathrm{mg} / \mathrm{L}$ indicating statistically significant genotoxicity. At the concentration of $2.0 \mathrm{mg} /$ $\mathrm{L}$, statistically significant cytotoxicity was evidenced by the reduction of the mitotic index (Table 3).

\subsection{Trad-MCN test}

In $T$. pallida, the results showed that none of the tested concentrations to both metallic-insecticides were able to induce micronucleus formation in a significantly way. However, the frequency of micronucleus (Fig. 2) induced by the metallic-insecticide [2] were higher than metallic-insecticide [1] (Table 4), especially in $1.0 \mathrm{mg} / \mathrm{L}$ (two-fold higher) and in $2.0 \mathrm{mg} / \mathrm{L}$ (three-fold higher).

\section{Discussion}

Higher plants enable detecting, cytologically, mutagens that cause cell inhibition, induction of chromosomal, numerical and structural aberrations, ranging from chromosome fragmentation to the disorganization of the mitotic spindle (Tedesco and Laughinghouse, 2012). The use of these organisms is simple, confident and cost-effective (Geras'kin et al., 2011). Thus, the A. cepa test and the Trad-MCN test enabled the evaluation of the

Table 1

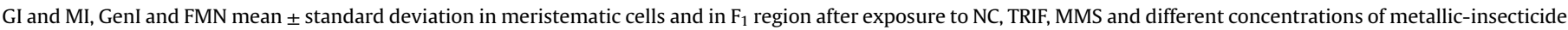
$\left[\mathrm{Mg}(5-\mathrm{Cl}\right.$-phen $)($ hesperetin $\left.)\left(\mathrm{H}_{2} \mathrm{O}\right)_{2}\right]\left(\mathrm{CH}_{3} \mathrm{COO}\right)[1]$.

\begin{tabular}{|c|c|c|c|c|c|c|}
\hline \multirow[t]{2}{*}{ Treatments } & \multirow[t]{2}{*}{ Bioassays } & \multirow[t]{2}{*}{ GI (\%) } & \multirow[t]{2}{*}{ MI } & \multirow[t]{2}{*}{ GenI } & \multicolumn{2}{|l|}{ FMN } \\
\hline & & & & & Meristematic region & $F_{1}$ region \\
\hline \multirow[t]{3}{*}{ Control groups } & $\mathrm{NC}$ & 93.50 & $4.71 \pm 14.49$ & $0.10 \pm 0.16$ & 0 & 0 \\
\hline & TRIF & 75.00 & $3.75 \pm 10.32$ & $0.76 \pm 0.77^{*}$ & $0.57 \pm 0.68^{*}$ & $0.30 \pm 0.27^{*}$ \\
\hline & MMS & 73.00 & $5.46 \pm 13.00$ & $0.72 \pm 0.36^{*}$ & $1.69 \pm 1.79^{*}$ & $029 \pm 0.33^{*}$ \\
\hline \multirow[t]{3}{*}{ Concentrations (mg/L) } & 0.5 & 88.00 & $3.64 \pm 10.64$ & $0.15 \pm 0.12$ & $0.07 \pm 0.10$ & $0.01 \pm 0.03$ \\
\hline & 1.0 & 94.00 & $3.27 \pm 10.28$ & $0.11 \pm 0.11$ & $0.05 \pm 0.09$ & $0.01 \pm 0.04$ \\
\hline & 2.0 & 93.00 & $3.15 \pm 6.23$ & $0.29 \pm 0.14^{*}$ & $0.07 \pm 0.06^{*}$ & $0.01 \pm 0.04$ \\
\hline
\end{tabular}

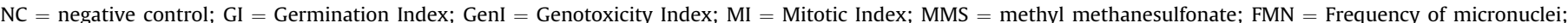
TRIF = Trifluralin

${ }^{*} \mathrm{p}<0.05$ statistically significantly when compared to NC using Kruskall-Wallis test. 

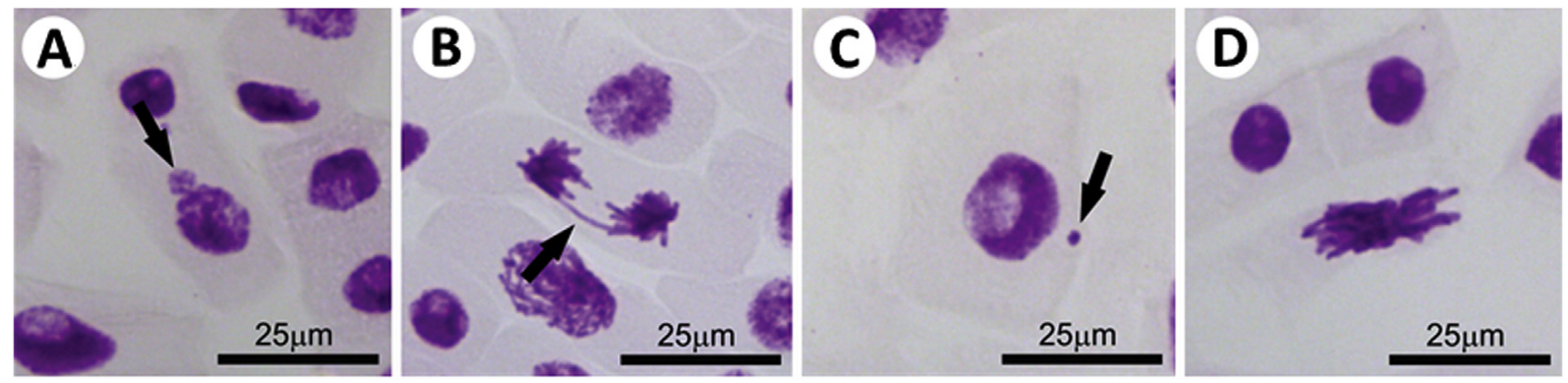

Fig. 1. Chromosomal aberrations observed in meristematc cells of A. cepa exposed to metallic-insecticides $\left[\mathrm{Mg}(5-\mathrm{Cl}\right.$-phen $)($ hesperetin $\left.)\left(\mathrm{H}_{2} \mathrm{O}\right)_{2}\right]\left(\mathrm{CH}_{3} \mathrm{COO}\right)(\mathrm{A}, \mathrm{B}$ and $\mathrm{C})$ and $[\mathrm{Mg}(5-$ methyl-phen)(hesperetin) $\left.\left(\mathrm{H}_{2} \mathrm{O}\right)_{2}\right]\left(\mathrm{CH}_{3} \mathrm{COO}\right)(\mathrm{D})$. A. nuclear bud; B. anaphasic bridges; C. micronucleus; D. metaphase with adherence.

Table 2

GI and MI, GenI and FMN mean \pm standard deviation in meristematic cells after exposure to NC, TRIF, MMS and different concentrations of metallic-insecticide [Mg(5-methylphen $)($ hesperetin $\left.)\left(\mathrm{H}_{2} \mathrm{O}\right)_{2}\right]\left(\mathrm{CH}_{3} \mathrm{COO}\right)[2]$.

\begin{tabular}{llllll}
\hline Treatments & Bioassays & GI $(\%)$ & MI & GenI & FMN \\
\hline Control groups & NC & 82.00 & $6.17 \pm 2.65$ & $0.02 \pm 0.08$ & $0.04 \pm 0.11$ \\
& TRIF & 54.00 & $4.98 \pm 2.34$ & $0.49 \pm 0.53^{*}$ & $1.81 \pm 1.30^{*}$ \\
\hline Concentrations (mg/L) & MMS & 88.50 & $4.99 \pm 2.05$ & $0.14 \pm 0.21^{*}$ & $0.59^{*}$ \\
& 0.5 & 92.50 & $4.53 \pm 1.55$ & $0.00 \pm 4.34^{*}$ \\
\hline & 1.0 & 87.50 & $4.74 \pm 1.68$ & $0.29^{*}$ & $0.09 \pm 0.25$ \\
& 2.0 & 89.50 & $3.60 \pm 1.21^{*}$ & 0.27 \\
\hline
\end{tabular}

$\mathrm{NC}=$ negative control; GI = Germination Index; GenI = Genotoxicity Index; MI = Mitotic Index; MMS = methyl methanesulfonate; FMN = Frequency of MN; TRIF = Trifluralin ${ }^{*} \mathrm{p}<0.05$ statistically significantly when compared to NC using Kruskall-Wallis test.

Table 3

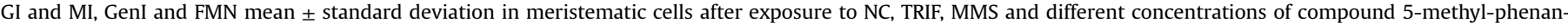
throline [3] found in metallic-insecticide [2].

\begin{tabular}{|c|c|c|c|c|c|}
\hline Treatments & Bioassays & GI (\%) & MI & GenI & FMN \\
\hline Control groups & $\begin{array}{l}\text { NC } \\
\text { TRIF } \\
\text { MMS }\end{array}$ & $\begin{array}{l}59.50 \\
28.00 \\
47.50\end{array}$ & $\begin{array}{l}4.04 \pm 1.58 \\
4.8 \pm 2.25 \\
6.67 \pm 2.41^{*}\end{array}$ & $\begin{array}{l}0.08 \pm 0.21 \\
1.91 \pm 2.11^{*} \\
1.39 \pm 1.01^{*}\end{array}$ & $\begin{array}{l}0.23 \pm 0.36 \\
0.92 \pm 0.91^{*} \\
5.91 \pm 3.56^{*}\end{array}$ \\
\hline Concentrations (mg/L) & $\begin{array}{l}0.5 \\
1.0 \\
2.0\end{array}$ & $\begin{array}{l}67.50 \\
76.50 \\
66.50\end{array}$ & $\begin{array}{l}3.95 \pm 1.16 \\
3.76 \pm 1.33 \\
2.52 \pm 1.68^{*}\end{array}$ & $\begin{array}{l}0.23 \pm 0.28^{*} \\
0.09 \pm 0.14 \\
0.09 \pm 0.25\end{array}$ & $\begin{array}{l}0.52 \pm 1.14 \\
0.18 \pm 0.26 \\
0.57 \pm 0.65\end{array}$ \\
\hline
\end{tabular}

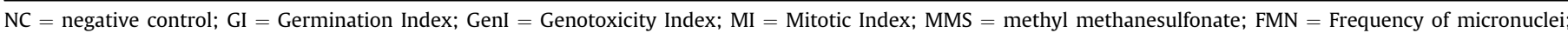
TRIF $=$ Trifluralin

${ }^{*} \mathrm{p}<0.05$ statistically significantly when compared to NC using Kruskall-Wallis test.

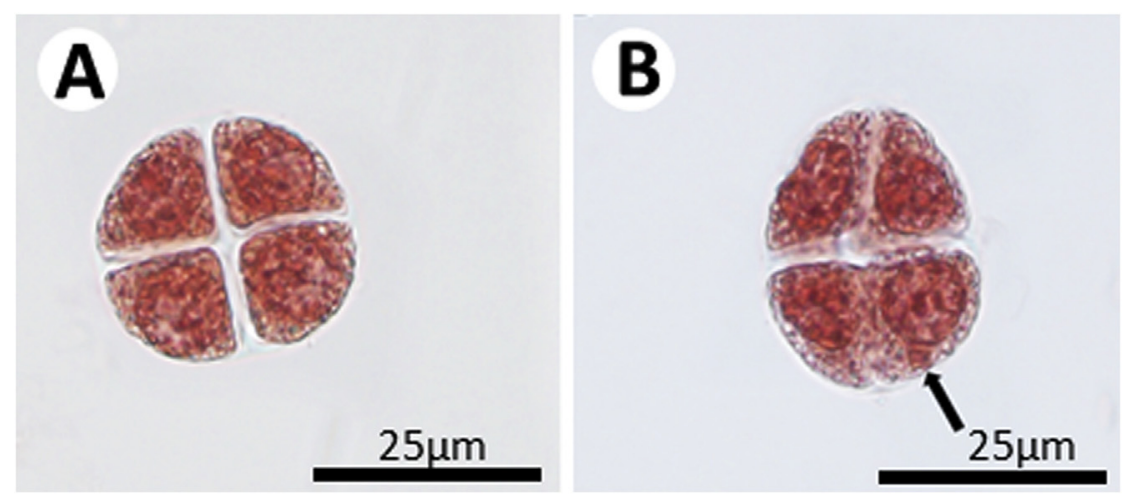

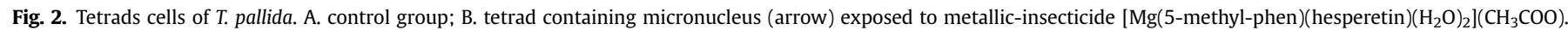

toxicity, genotoxicity and chromosomal instability caused by the metallic-insecticides [1], [2] and one of the components of its formula [3].

In the A. cepa test, the two metallic-insecticides did not change the germination rate, since the seeds germinated at a similar rate to control soil. Positive controls had low germination due to the inhibitory action of trifluralin and MMS (Fernandes et al., 2013). The analysis of mitotic index revealed that only metallic-insecticide [2] can be cytotoxic. According to Fernandes et al. (2007), both the increase and the decrease of MI are important indicators of 
Table 4

Frequency of micronucleus and mean \pm standard deviation in tetrads cells of $T$. pallida after exposure to NC, MMS and different concentrations of the metallicinsecticides.

\begin{tabular}{|c|c|c|c|}
\hline Treatments & Bioassays & Metallic-insecticide [1] & Metallic-insecticide [2] \\
\hline Control groups & $\begin{array}{l}\text { NC } \\
\text { MMS }\end{array}$ & $\begin{array}{l}0.06 \pm 0.17 \\
0.38 \pm 0.51\end{array}$ & $\begin{array}{l}0.06 \pm 0.13 \\
0.53 \pm 0.41\end{array}$ \\
\hline Treatments (mg/L) & $\begin{array}{l}0.5 \\
1.0 \\
2.0\end{array}$ & $\begin{array}{l}0.06 \pm 0.17 \\
0.11 \pm 0.19 \\
0.06 \pm 0.13\end{array}$ & $\begin{array}{l}0.08 \pm 0.18 \\
0.24 \pm 0.33 \\
0.21 \pm 0.34\end{array}$ \\
\hline
\end{tabular}

$\mathrm{NC}=$ negative control; MMS = methyl methanesulfonate; metallic-insecticide $[1]=\left[\mathrm{Mg}(5-\mathrm{Cl}\right.$-phen $)($ hesperetin $\left.)\left(\mathrm{H}_{2} \mathrm{O}\right)_{2}\right]\left(\mathrm{CH}_{3} \mathrm{COO}\right)$; metallic-insecticide $[2]=[\mathrm{Mg}(5$ methyl-phen)(hesperetin) $\left.\left(\mathrm{H}_{2} \mathrm{O}\right)_{2}\right]\left(\mathrm{CH}_{3} \mathrm{COO}\right)$.

environmental pollution: when it is lower than in the control, there is alteration in the development of the organism; when it is higher, the increase of cell division can indicate a disorder in cell proliferation and, even, the formation of a tumor.

Using the A. cepa test system, a decrease in the number of mitosis was also found by Akdeniz and Özmen (2011), when studying the biopesticide oximatrin, and by Anjana and Thoppill (2013) when studying aqueous extracts of the plant Pogostemom auricularius. In Vicia faba, the natural formicide Macex ${ }^{\mathbb{B}}$ was also responsible for decreasing the mitotic index (Cotelle et al., 2012). The decrease in mitotic activity may have been caused by the inhibition of DNA synthesis or by the blockage of the G2 phase of the cell cycle, preventing the cell from dividing (Türkoglu, 2008).

Regarding genotoxicity, chromosomal aberrations were induced in the meristematic region of $A$. cepa by metallic-insecticides [1] and [2]. Metallic-insecticide [1] induced aberrations only at $2.0 \mathrm{mg} /$ $\mathrm{L}$ and compound [2] at $0.5 \mathrm{mg} / \mathrm{L}$ and $1.0 \mathrm{mg} / \mathrm{L}$. These alterations are characterized both by changes in chromosome structure and in its total number and can occur spontaneously or as a result of exposure to chemical and physical agents (Russel, 2002).

Among the aberrations induced by these compounds, anaphases with bridge were the most frequent. According to Hoffelder et al. (2004), anaphasic bridges are a common cause and an indicator of chromosomal instability. This phenomenon can occur as a result of chromosomal adherence (Marcano et al., 2004; Brossi, 2008), by telomere shortening (De Lange, 2002) or by an unequal translocation or inversion of chromosome segments (Gömürgen, 2005).

According to the results obtained, the chromosomal bridges observed here were probably formed by chromosomal adherence, since this alteration was one of the most induced by the two compounds. According to Marcano et al. (1999) and Kurás (2004), chromosomal adherence is a type of abnormality that does not affect the DNA molecule itself, but the protein matrix of the chromatin, probably the amount of histones or other proteins that regulate its structure.

Adherent chromosomes have been observed in roots of $A$. cepa after treatment with various metals, such as $\mathrm{Hg}$, Ni and $\mathrm{Cu}$ (Fiskejö, 1993; Monte-Egito et al., 2007; Francisco et al., 2014). Although the tested compound contained the metal magnesium, studies have shown that it has no genotoxic effects at physiologically relevant doses. Once this substance is essential to the organism, magnesium plays an important role in genomic stability, such as in DNA replication and protein synthesis, having a function as a cofactor in repair proteins, in the maintenance of the anti-oxidant status of the cell and in the regulation of cell cycle and apoptosis (Hartwig, 2001).

However, both histones and magnesium bind to DNA through the same site, the phosphate groups (Naora et al., 1961). Therefore, a competition may have occurred between these two components, leading, consequently, to the formation of the aberrations found.

The presence of micronuclei, an indicative of chromosomal instability, was only observed in cells of the meristematic region in
A. cepa at the highest concentration of the metallic-insecticide [1]. However, the analysis of the $F_{1}$ region demonstrated that such damage was not passed on to the other cells of the organism. According to Ma et al. (1995), after the end of mitotic division in the meristematic cells, the possible DNA damage of these cells would be visualized in the form of micronuclei in their daughter cells, which correspond to the $F_{1}$ cells in A. cepa. In the case of metallicinsecticide [1], the cellular repair mechanism was able to reverse the damage caused, preventing fixation of micronuclei in the $F_{1}$ region cells.

In T. pallida, although none of the complexes induced significant formation of micronuclei, the metallic-insecticide [2] showed higher frequency. The results support those obtained for $A$. сера, where metallic-insecticide [2] were more toxic. The analyses of micronucleus in T. pallida are realized in tetrads cells, which are under meiosis process. According to Steinkellner et al. (1998), the evaluation of micronucleus in meiosis cells is more sensitive than in mitosis cells when exposed to heavy metals and $\gamma$ radiation. However, in this study, the A. cepa test was more sensitive. In a study performed by Misik et al. (2014) with cytostatic drugs, the genotoxicity was quite similar, regardless if induction of MN was monitored in T. pallida or in A. cepa.

Genotoxic and mutagenic tests are extremely important in studies evaluating the efficacy and safety of molecules in the early stages of the development of new substances (Jena et al., 2002). Akhtar et al. (2012), when evaluating a herbo-metallic formulation in human lymphocytes, concluded that the highest concentrations tested are responsible for inducing genotoxicity. Vardhini et al. (2010) found no formation of micronuclei induced by another herbo-metallic formulation. Natural formicides were evaluated by Cotelle et al. (2012) and Tiepo et al. (2010), and they concluded that their respective products can be considered environmentally safe.

Considering the two metallic-insecticides evaluated, metallicinsecticide [2] had significant cytotoxic and genotoxic results in different concentrations in $A$. cepa and induced higher micronucleus frequency in T. pallida, while metallic-insecticide [1] showed genotoxicity only at the highest concentration. In order to better understand the results, one of the components of the formulation of compound [2], 5-methyl-phenanthroline [3], was assessed using the same parameters. The results demonstrate that compound [3] can be related to the toxicity found in metallic-insecticide [2], once it showed cytotoxicity and genotoxicity. Studies with 1,10phenanthroline complexed with $\mathrm{Cu}(\mathrm{I})$ and $\mathrm{Cu}(\mathrm{II})$ have indicated that these substances can be toxic (Pope and Sigman, 1984; Florence et al., 1985; Goldstein and Czapski, 1986). According to Whittaker et al. (2001), phenantroline can be mutagenic even when is isolated.

Another component present in the formulas of metallicinsecticides corresponds to hesperetin, a flavonoid found in citrus fruits. However, it seems to have no relation to the positive results, although some flavonoids have shown genotoxicity in eukaryotic and prokaryotic systems (Boos and Stopper, 2000; Heo et al., 2001; 
Misra et al., 2002). According to Snyder and Gillies (2002), hesperetin has no ability to intercalate with DNA, and in a 2003 study, the same authors demonstrated that hesperetin can reduce by $80 \%$ the induction to formation of micronuclei by other flavonoid, genistein.

However, it is important to consider that transition metals, such as copper and manganese, can affect the genotoxicity of some flavonoids, although for hesperetin no alteration has been verified (Snyder and Gillies, 2002).

Considering the two metallic-insecticides evaluated, the metallic-insecticide [2] obtained results that evidence some toxic action to both test organisms. The analysis of one of the components of its formula revealed that it can be related to the positive results, since it also has shown toxic effects for the parameters evaluated. Therefore, metallic-insecticide [1] is found to be an environmentally safer alternative to combat leaf-cutting ants.

\section{Conflict of interest}

The authors declare that they have no conflict of interest.

\section{Acknowledgements}

The authors thank Fundação de Amparo à Pesquisa do Estado de São Paulo (FAPESP, process No. 2012/12019-5) for the financial support, Prof. Dr. Cintya A. Christofoletti for the assistance in preparing the bioassays and Prof. Dr. João Batista Fernandes and Prof. Dra. Rose Maria Carlos for the synthesis of the metallic-insecticides.

\section{References}

ABRAISCA - Associação Brasileira das Empresas Fabricantes de Iscas Inseticidas, 2011. ABRAISCA Defende a Sulfluramida (Accessed 24 August 2015). http:// www.abraisca.org.br/index.php/noticias/8-abraisca-defende-a-sulfluramida.

Akdeniz, D., Özmen, A., 2011. Antimitotic effects of the biopesticideoxymatrine. Caryologia 64, 117-120.

Akhtar, K., Malla, T.M.D., Malla, B.A., Bhat, H.K., 2012. Assessment of genotoxic potential of qurskushtaqalai: a unaniherbo-metallic formulation. J. Herb. Med. e Toxicol. 6, 49-54.

Anjana, S., Thoppill, J.E., 2013. Analysis of cytotoxic potential of the aqueous leaf extracts of Pogostemonauricularius (L.) Hassk.using Allium cepa root tip assay. Int. J. Res. Dev. Pharm. Life. Sci. 2, 562-566.

Bianchi, J., Fernandes, T.C.C., Marin-Morales, M.M.A., 2016. Induction of mitotic and chormossomal abnormalities on Allium cepa cells by pesticides imidacloprid and sulfentrazone and the mixture of them. Chemosphere 144, 475-483.

Boersma, M.G., Vervoot, J., Szymusiak, H., Lemanska, K., Tyrakowska, B., Cenas, N., Segura-Aguilar, J., Rietjens, I.M.C.M., 2000. Regioselectivity and reversibility of the glutathione conjugation of quercetinquinonemethide. Chem. Res. Toxicol. 13, 185-191.

Batista, N.J.C., Cavalcante, A.A.C.M., Oliveira, M.G., Medeiros, E.C.N., Machado, J.L., Evangelista, S.R., Dias, J.F., Santos, C.E.I., Duarte, A., Silva, F.R., Silva, J., 2016. Genotoxic and mutagenic evaluation of water samples from a river under the influence of different anthropogenic activities. Chemosphere 164, 134-141.

Boos, G., Stopper, H., 2000. Genotoxicity of several clinically used topoisomerase Il inhibitors. Toxicol. Lett. 116, 7-16.

Bots, J., De Bruyn, L., Snijkers, T., Van Den Branden, B., Van Gossum, H., 2010. Exposure to perfluorooctane sulfonic acid (PFOS) adversely affects the life-circle of the damselfly Enallagma cyathigerum. Environ. Pollut. 158, 901-905.

Brossi, M.J.L., 2008. Ecotoxicologia de um Sistema Florestal de Eucalipto Tratado com Lodo de Esgoto. São Paulo University. PhD Thesis.

Cotelle, S., Testolin, R.C., Foltête, A.S., Bossardi-Rissardi, G., Silveira, R.A. Radetski, C.M., 2012. Genotoxicity potential of a new natural formicide. Environ. Sci. Pollut. Res. 19, 628-635.

De Lange, T., 2002. Protection of mammalian telomeres. Oncogene 21, 532-540.

Fan, Y., Jin, Y.H., Ma, Y.X., Zhang, Y.H., 2005. Effects of perfluorooctanesulfonate on spermiogenesis function of male rats. Wei. Shehg. Yan. Jiu 34, 37-39.

Fernandes, T.C.C., Mazzeo, D.E.C., Marin-Morales, M.A., 2007. Mechanism of micronuclei formation in polyploidizated cells of Allium cepa exposed to trifluralin herbicide. Pest. Biochem. Physiol. 88, 252-259.

Fernandes, T.C.C., Pizano, M.A., Marin-Morales, M.A., 2013. Characterization, modes of action and effects of trifluralin: a review. In: Price, A.J., Kelton, J.A. (Eds.), Herbicides - Current Research and Case Studies in Use, InTech, Croatia, pp. 489-515.

Fiskejö, G., 1993. The Allium cepa test in wastewater monitoring. Environ. Toxic. Water 8, 291-298.
Florence, T.M., Stauber, J.L., Mann, K.J., 1985. The reaction of copper-2,9-dimethyl1,10-phenanthroline with hydrogen peroxide. J. Inorg. Biochem. 24, 243-254.

Francisco, A., Christofoletti, C.A., Fontanetti, C.S., 2014. Evaluation of allowed parameters for nickel in freshwater bodies using the Allium cepa test. Semina 35 49-60.

Geras'kin, S., Evseeva, T., Oudalova, A., 2011. Plants as a tool for the environmental health assessment. In: Nriagu, J.O. (Ed.), Encyclopedia of Environmental Health. Elsevier, Burlington, pp. 571-579.

Goldstein, S., Czapski, G., 1986. Mechanisms of the reactions of some copper complexes in the presence of DNA with superoxide, hydrogen peroxide, and molecular oxygen. J. Am. Chem. Soc. 108, 2244-2250.

Gömürgen, A.N., 2005. Cytological effect of the potassium metabisulphite and potassium nitrate food preservative on root tips of Allium cepa L. Cytologia 70, $119-128$.

Hartwig, A., 2001. Role of magnesium in genomic stability. Mutat. Res. 475, 113-121.

Hebling, M.J.A., Maroti, P.S., Bueno, O.C., Silva, A.O., Pagnocca, F.C., 1996. Toxic effects of leaves of Ricinus communis (Euphorbiaceae) to laboratory nest of Atta sexdens rubropilosa (Hymenoptera: formicidae). B. Entomol. Res. 86, 253-256.

Heo, M.Y., Sohn, S.J., Au, W.W., 2001. Antigenotoxicity of galangin as a cancer chemopreventive agent candidate. Mutat. Res. 488, 135-150.

Hoffelder, D.R., Luo, L., Burke, N.A., Watkins, S.C., Gollin, S.M., Saunders, W.S., 2004 Resolution of anaphase bridges in cancer cells. Chromosoma 112, 389-397.

Jena, G.B., Kaul, C.L., Ramarao, P., 2002. Genotoxicity testing, a regulatory requirement for drug discovery and development: impact of ICH guidelines. Indian J. Pharmacol. 34, 86-99.

Kähkönen, E., Nordström, K., 2008. Toward a nontoxic poison: current trends in (European Union) biocides regulation. Integr. Environ. Assess. Manag. 4 471-477.

Kirsche-Volders, M., Plas, G., Elhajouji, A., Lukamowicz, M., Gonzalez, L., Loock, K.V., Decordier, I., 2011. The in vitro MN assay in 2011: origin and fate, biological significance, protocols, high throughput methodologies and toxicological relevance. Arch. Toxicol. 85, 873-899.

Kuchy, A.H., Wani, A.A., Kamili, A.N., 2016. Cytogenetic effects of three commercially formulated pesticides on somatic and germ cells of Allium cepa. Environ. Sci. Pollut. R. 23, 6895-6906.

Kurás, L., 2004. Characterization of Protein-DNA Association in Vivo by Chromatin Immuno-precipitation. In: Dickson, R.C., Mendenhall, M.D. (Eds.), Signal Transduction Protocols, Methods in Molecular Biology. Humana Press Inc, Totowa, pp. 147-162.

Leme, D.M., Marin-Morales, M.A., 2009. Allium cepa test in environmental monitoring: a review on its application. Mutat. Res. 682, 71-81.

Liman, R., Cigerci, I.H., Öztürk, N.S., 2015. Determination of genotoxic effects of Imazethapyr herbicide in Allium ceparoots cells by mitotic activity, chromosome aberration, and comet assay. Pestic. Biochem. Phys. 118, 38-42.

Luebker, D.J., York, R.G., Hansen, K.J., Moore, J.A., 2005. Neonatal mortality in utero exposure to perfluorooctanesulfonate (PFOS) in Sprague-Dawley rats: doseresponse, and biochemical and pharamacokinect parameters. Toxicology 215, $149-169$.

Lutterbeck, C.A., Kern, D.I., Machado, E.L., Kümmerer, K., 2015. Evaluation of the toxic effects of four anti-cancer drugs in plant bioassays and its potency for screening in the context of waste water reuse for irrigation. Chemosphere 135, 403-410.

Ma, T.H., 1999. The international program on plant bioassays and the report of the follow-up study after the hands-on workshop in China. Mutat. Res. 426, 103-106.

Ma, T.H., Cabrera, G.L., Chen, R., Gill, B.S., Sandhu, S.S., Vanderberg, A.L., Salamone, M., 1994. Tradescantia micronucleus bioassay. Mutat. Res. 310, $221-230$.

Ma, T.H., Xu, Z., Xu, C., McConnel, H., Rabago, E.V., Arreola, G.A., 1995. The improved Allium/Vicia root tip micronucleus assay for clastogenicity of environmental pollutants. Mutat. Res. 334, 185-195.

Macgregor, J.T., Jurd, L., 1978. Mutagenicity of plant flavonoids: structural requirements for mutagenic activity in Salmonella typhimurium. Mutat. Res. 54 297-309.

Marcano, L., Carruyo, I., Del Campo, A., Montiel, X., 2004. Cytotoxicity and mode of action of maleic hydrazide in root tips of A. cepa L. Environ. Res. 94, 221-226.

Marcano, L., Carruyo, I., Montiel, X., Moreno, P., 1999. Inhibición de laactividadbiosintética nucleolar inducidas por elplomoenmeristemos radiculares de cebolla (Allium cepa). Rev, Fac. Agron. Univ. Zulia 16, 476-487.

Martins, N.C.M., Souza, V.V., Souza, T.S., 2016. Cytotoxic, genotoxic and mutagenic effects of sewage sludge on Allium cepa. Chemosphere 148, 481-486.

Mello, M.L.S., Vidal, B.C., 1978. A Reação de Feulgen. Ciência Cult. 30, 665-676.

Middleton, E., Kandaswami, C. 1994. The impact of plant flavonoids on mammalian biology: implications for immunity, inflammation and cancer. In: HARBONE, J.B. (Org.). The Flavonoids. Chapman \& Hall, London, pp. 619-652.

Misik, M., Ma, T.H., Nersesyan, A., Monarca, S., Kim, J.K., Knasmueller, S., 2011. Micronucleus assays with Tradescantia pollen tetrads: an update. Mutagenesis 26, 215-221.

Misik, M., Pichler, C., Rainer, B., Filipic, M., Nersesyan, A., Knasmueller, S., 2014 Acute toxic and genotoxic activities of widely used cytostatic drugs in higher plants: possible impact on the environment. Environ. Res. 135, 196-203.

Misra, R.R., Hursting, S.D., Perkins, S.N., Sathyamoorthy, N., Mirsalis, J.C., Riccio, E.S. Crowell, J.A., 2002. Genotoxicity and carcinogenicity studies of soy isoflavones. Int. J. Toxicol. 21, 277-285.

Monte-Egito, L.C., Medeiros, M.G., Medeiros, S.R.B., Agnez-Lima, L.F., 2007. Cytotoxi 
and genotoxic potential of surface water from the Pitimbu river, northeastern/ RN Brazil. Genet. Mol. Biol. 30, 435-441.

Naora, H., Naora, H., Mirsky, A.E., Allfrey, V.G., 1961. Magnesium and calcium in isolated cell nuclei. J. Gen. Physiol. 44, 713-742.

Oliveira, R.M.M., Souza, J.F.F., de Aguiar, I., Silva, M.F.G.F., Fernandes, J.B., Carlos, R.M.J., 2013. Structural effects on the hesperidin properties obtained by chelation to magnesium complexes. Inorg. Biochem. 129, 35-42.

Olivero-Verbel, J., Tao, L., Johson-Restrepo, B., Guette-Fernández, J., Baldiris-Avila, R. O'byrne-Hoyos, I., Kurunthachalam, K., 2006. Perfluorooctanesulfonate and related fluorochemicals in biological samples from the north coast of Colombia. Environ. Pollut. 142, 367-372.

Pedro-Escher, J., Maziviero, G.T., Fontanetti, C.S., 2014. Mutagenic action of sugarcane vinasse in the TradescantiaPallida test system. Ecosyst. Ecogr. 4, 2-4.

Pichler, C., Filipic, M., Kundi, M., Rainer, B., Knasmueller, S., Misik, M., 2014. Assessment of genotoxicity and acute toxic effect of the imatinib mesylate in plant bioassays. Chemosphere 115, 54-58.

Pope, L.E., Sigman, D.S., 1984. Secondary structure specificity of the nuclease activity of the 1,10-phenanthroline-copper complex. PNAS 81, 3-7.

Rank, J., Nielsen, M.H., 1997. Allium cepa anaphase-telophase root tip chromosome aberration assay on $\mathrm{N}$-methyl-N-nitrosourea, maleic hydrazide, sodium azide, and ethyl methanesulfonate. Mut. Res. 390, 121-127.

Rodríguez, Y.A., Christofoletti, C.A., Pedro, J., Bueno, O.C., Malaspina, O. Ferreira, R.A.C., Fontanetti, C.S., 2015. Allium cepa and Tradescantia pallida bioassays to evaluate effects of the insecticide imidacloprid. Chemosphere 120 $438-442$.

Russel, P.J., 2002. Chromosomal mutation. In: Cummings, B. (Ed.), Genetics. Pearson Education Inc, São Francisco, pp. 595-621.

Schoereder, J.H., Silva, H.M.M., Carvalho, A.F., Muscardi, D.C., 2012. Proposed lime stone treatment as pest control fails for the leaf-cutting ant Atta sexdens rubropilosa. Crop Prot. 42, 79-82.

Silva, I.D., Rodrigues, A.S., Gaspar, J., Laires, A., Rueff, J., 1997. Metabolism of galangin by rat cytochromes P450: relevance to the genotoxicity of galangin. Mut. Res. 393, 247-257.

Snyder, R.D., Gillies, P.J., 2002. Evaluation of the clastogenic, DNA intercalative and topoisomerase II-interactive properties of bioflavonoids in Chinese hamster V79 cells. Environ. Mol. Mutagen 40, 266-276.

Snyder, R.D., Gillies, PJ., 2003. Reduction of genistein clastogenicity in Chinese hamster V79 cells by daidzein and other flavonoids. Food. Chem. Toxicol. 41,
$1291-1298$.

Steinkellner, H., Mun-Sik, K., Helma, C, Ecker, S, Ma, T.H., Horak, O, Kundi, M., Knasmüller, S., 1998. Genotoxic effects of heavy metals: comparative investigation with plant bioassays. Environ. Mol. Mutagen 31, 183-191.

Stockholm Convention on Persistent Organic Pollutants, 2009. Adoption of Amendments to Annexes A, B and C.

Taniyasu, S., Kannan, K., Horii, Y., Hanari, N., Yamashita, N., 2003. A survey of perfluorooctanesulfonate and related perfluorinated organic compounds in water, fish, birds and humans from Japan. Environ. Sci. Technol. 37, 2634-2639.

Tedesco, S.B., Laughinghouse, H.D., 2012. Bioindicator of genotoxicity: the allium cepatest. In: Srivastava, J.K. (Ed.), Environmental Contamination. InTech, Croatia.

Tiepo, E.N., Corrêa, A.X.R., Resgalla, C., Cotelle, S., Férard, J.F., Radetski, C.M., 2010. Terrestrial short-term ecotoxicity of a green formicide. Ecotox. Environ. Safe 73, 939-943.

Türkoglu, S., 2008. Evaluation of genotoxic effects of sodium propionate, calcium propionate and potassium propionate on the root meristem cells of Allium cepa. Food. Chem. Toxicol. 46, 2035-2041.

USEPA, 2008. Special Review and Registration Division. Sulfluramid Registration Review Final Decision. Registration Review Case 7411. http://www.epa.gov/ fedrgstr/EPA-PEST/2008/May/Day-16/p10919.pdf (Accessed 24 August 2015).

Verreault, J., Houde, M., Gabrielsen, G.W., Berger, U., Haukas, M., Letcher, R.J., Muir, D.C. 2005. Perfluorinated alkyl substance in plasma, liver, brain and eggs of glaucous gulls (Larushy perboreus) from the Norwegian arctic. Envron. Sci. Technol. 39, 7439-7445.

Vardhini, N., Sathya, T.N., Murthy, P., 2010. Assessment of genotoxic potential of herbomineral preparations - bhasmas. Curr. Sci. India 99, 1096-1100.

Ventura-Camargo, B.C., Angelis, D.F., Marin-Morales, M.A., 2016. Assessment of the cytotoxic, genotoxic and mutagenic effects of the commercial black dye in Allium cepa cells before and after bacterial biodegradation treatment. Chemosphere $161,325-332$.

Whittaker, P., Seifried, H.E., San, R.H.C., Clarke, J.J., Dunkel, V.C., 2001. Genotoxicity of iron chelators in L5178Y mouse lymphoma cells. Environ. Mol. Mutagen 38, $347-356$.

Zanuncio, J.C., Mageste, G., Pereira, J.M.M., Zanetti, R., 2000. Utilización del cebo Mirex-S (Sulfluramida 0.3\%) para el control de Atta sexdens rubropilosa (Hymenoptera: formicidae) em área estratificada de hormigueros. Rev. Colomb. Entomol. 26, 157-160. 